\title{
Agro-climatic onset of cropping season: A tool for determining optimum date of sowing in dry zones of southern Karnataka
}

\author{
LINGARAJ HUGGI ${ }^{*}$, H.S. SHIVARAMU, M.H. MANJUNATAHA, D.V. SOUMYA, P. VIJAYA \\ KUMAR $^{1}$ and MANOJ M. LUNAGARIA ${ }^{2}$
}

\author{
AICRP on Agrometeorology, University of Agricultural Sciences, GKVK, Bangalore \\ ${ }^{I}$ ICAR-Central Research Institute for Dryland Agriculture, Hyderabad 500059 \\ ${ }^{2}$ Dept. of Agril. Meteorology, Anand Agril. University, Anand Gujarat 388015
}

${ }^{*}$ Corresponding author's e-mail: lingarajhuggi@gmail.com

\begin{abstract}
The study was conducted to analyse the rainfall pattern of dry farming zones of Southern Karnataka to arrive at proper date of sowing by considering parameters like threshold rainfall $(20 \mathrm{~mm})$, threshold dry day $(2.5 \mathrm{~mm})$ and threshold dry spell period (10 days) as a main defining parameters for decision making in sowing of major crops (finger millet, pigeonpea, groundnut, etc.). In all the three zones, the agro-climatic onset of cropping season was earlier as compared to meteorological onset (June $1^{\text {st }}$ week) due to bimodal distribution of rainfall having its peaks in May and September month. In Central Dry Zone, Southern Dry Zone and Eastern Dry Zone, fourteenth June, thirteenth June and twentythird May were the agro-climatic onset dates (average of all stations in each zone), respectively. Station wise analysis of the rainfall revealed different agro-climatic onset dates. Ninth May in central dry zone, eighth May in eastern dry zone and fifth May in southern dry zone were the earliest onset dates. These variations in between zonal and station specific onset dates were due to spatio-temporal variations in rainfall. Therefore, advancements in sowing of crops based on the agro-climatic onset should be taken into account for betterment of crop production.
\end{abstract}

Key words: Sowing date, onset date, agro-climatic onset, dry zones, southern Karnataka.

In tropical countries, the economy and food security of the rural population are strongly dependent on farming. Indeed, rain-fed crops are the main source of food, livestock fodder and incomes. In India, a typical tropical country, dryland agriculture occupies $68 \%$ of India's cultivated area and supports $40 \%$ of the human and $60 \%$ of the livestock population. It produces $44 \%$ of food requirements, thus has and will continue to play a critical role in India's food security (Harish et al., 2004). In dry farming zones of southern Karnataka, major soil types are sandy loam (Alfisols), some of drought tolerant crops like pigeon pea, finger millet etc. are grown. One of the most important risk factors is the high spatial and temporal variability of rainfall across the region (Ravindrababu et al., 2010); this is exacerbated by poor soil fertility (Wani et al. 2011). The rainy season lasts from April to November and receives between 528 to $1374 \mathrm{~mm}$ of rainfall with an average of 914 $\mathrm{mm}$ (Venkatesh et al. 2016). Several climatic factors such as seasonal rainfall amount, intra-seasonal rainfall distribution and dates of onset/cessation of the rains influence crop yields and determine the agricultural calendar (Sivakumar,
1988; Kesava Rao et al., 2013). In particular, the onset of the rainy season appears to be the most crucial information (Ingram et al., 2002; Barbier et al., 2009) for agricultural management since it determines the planting period (Tiwari et al., 1992; Sivakumar, 1992; Omotosho et al., 2000). The agro-climatic approach defines the onset as the optimal date that ensures sufficient soil moisture during planting and early growing periods to avoid crop failure after sowing (Sivakumar, 1988; Omotosho et al., 2000).

Traditionally, sowings begin as early as possible and coincide with the first substantial rainy event (Bacci et al., 1999), which occurs generally around one month before the full establishment of the monsoon (Sultan and Janicot, 2003). Since the monsoon season has not begun yet, the probability of a post-sowing dry spell is high, increasing the risk of a sowing failure. Farmers balance this risk, by resowing of the crop inducing a loss of seeds and an increase of labor devoted to re-sowing. Moreover, late sowings shorten the growing season and increase weed pressure and weeding (Andrews, 1973; Stoop et al., 1981). In this paper an attempt is made to illustrate how rainfall determines the 
choice of sowing date and evaluates the relationship between sowing and onsets dates defined using agro-climatic approaches.

\section{MATERIALS AND METHODS}

\section{Meteorological data}

Daily rainfall data records from each station falling under the respective taluk comprised by each zone were collected from Annual Reports of AICRPAM (All India Coordinated Research Project on Agrometeorology), UAS, GKVK, Bengaluru. The study area is located in South of Karnataka $\left(13.18^{\circ} \mathrm{E}\right.$ to $13.32^{\circ} \mathrm{E}$ and $75.82^{\circ}$ to $\left.76.59^{\circ} \mathrm{N}\right)$. A summary of zones under study, districts, taluks or stations falling under each zone is provided in Table 1 and meteorological stations used in the study along with their location and average annual rainfall amount is indicated in Table 2 .

\section{Onset of the rainy season}

Onset is defined using different methods that fall into two distinct approaches: a) the meteorological point of view based on first rains and, b) the agro-climatic one which considers crop suitability. Note that for onset definition, a day receiving at least $2 \mathrm{~mm}$ of rainfall is considered here after as wet.

\section{The meteorological onsets :}

The first wet day after April 15th of a 3-day wet spell receiving at least $20 \mathrm{~mm}$. Note that the $20 \mathrm{~mm}$ threshold corresponds roughly to the mean rainfall amount received in 3-day wet spell (i.e. $>1 \mathrm{~mm}$ ). Balme et al. (2005) defined a "meso-scale" onset date (here in after referred to as MSO) as the first day of a 2-day wet spell when at least $90 \%$ of stations record rainfall $(>1 \mathrm{~mm})$ at least during one day in a radius of $300 \mathrm{~km}$. This area is related to the mean scale of Meso Convective Systems (MCS)

\section{The agro-climatic onsets}

Based on the agro climatic onset concept (Sivakumar, 1988) and the work of Marteau et al. (2009), we defined the agro climatic onset date (here in after referred to as AO) as the date after $1^{\text {st }}$ May, when rainfall accumulated over three consecutive days is least $20 \mathrm{~mm}$ and when no dry spell within the next 30 days exceeds seven days.

Sowing date is defined as the day when simulated plant available water in soil is greater than $10 \mathrm{~mm}$ at the end of the day, followed by a 20-day period during which crop establishment is monitored. The juvenile stage of the crop is considered failed, triggering automatic re-sowing, if the simulated daily total biomass decreases during 11 out of 20 days. Simulated sowings are possible from 15 April to 31 August. Note that the ideal sowing date may not be "ideal" from an agro-ecological, agronomic, socio-economic point of view, since it does not take into account nutrient dynamics, pests and diseases, or labor availability.

A MATLAB GUI interface was developed by AICRP on Agrometeorology, Anand, Gujarat with taking into consideration of the above pre-requisites to determine the agro climatic onset. It runs on MATLAB runtime environment. The interface requires criteria specific inputs for determination of the agro-climatic onset. They are explained as follows.

Start date (calendar date): An estimated date of onset of rainfall, used for start the simulation of agro-climatic onset. In our case, April 1 is considered as a start date in order to check the influence of pre-monsoon showers on deciding the date of sowing in southern Karnataka.

Rainfall threshold (mm): Minimum amount of rainfall required to sow the crop. Major area under study is being a dryland, around $20 \mathrm{~mm}$ rainfall will be sufficient for sowing of major dryland crops like finger millet, pigeon pea and other crops (Morris and Zandstra, 1979).

Dry day threshold (mm): The minimum amount of soil moisture to meet the evaporation need of soil. In the study area major soils are red sandy loams. An amount of $2.5 \mathrm{~mm}$ soil moisture is considered and, if the soil moisture goes less than $2.5 \mathrm{~mm}$, that particular day is considered as a dry day.

Dry spell threshold (days): the maximum number of days that crop can sustain even after reaching the dry day threshold. That is, if the crop undergoes moisture stress even up to 10 days, there will not be considerable yield loses. In dryland like our study area, the crop can sustain up to 10 days even after reaching the dry day threshold. So, 10 days is considered as dry spell threshold for our study.

Dry spell search period (days): This is decided on the concept that ability of that particular crop to sustain after germination. If the dry spell occurs before this search period, the model postpones the sowing date to next moisture abundance period. If not, the first day of search period will be considered. In our case, 20 days is considered since crop will last up to 20 days since majority of dryland crops have ability to sustain up to 20 days with minor amounts of soil moisture.

After considering all above 'defining inputs', data is loaded using 'data' tab and run to indicate the dry and wet 
Table 1: Zones under study, Districts and taluks in Karnataka coming under each zone from where rainfall data was collected

\begin{tabular}{lll}
\hline Zone & District & Taluks/Stations \\
\hline Zone 4 & Chitradurga & Chtradurga, Hosadurga, Challakere, Molakalmuru, Holalkere, Hiriyuru \\
(Central & Davanagere & Davanagere, Harihara, Jagaluru \\
DryZone) & Tumakuru & Madhugiri, Pavaghadha, Sira, Chikkanayakanahalli \\
& Chikkamagaluru & Kaduru \\
Zone 5 & Tumakuru & Gubbi, Koratagere \\
(Eastern & Bangalore (rural) & Devanahhali, Doddaballapura, Nelamangala, Hosakote \\
DryZone) & Ramnagara & Ramnagara, Magadi, Kanakapura, Channapattana \\
& Bangalore (urban) & Bangalore (north), Bangalore (south), Anekal \\
& Kolar & Kolar, Maluru, Bangarapete, Shrinivasapura, Mulabagilu \\
& Chikkaballapur & Chikkaballapur, Shiddalaghatta, Chintamani, Gudibande, Gouribidanuru, Bagepalli \\
Zone 6 & Mandya & Mandya, madduru, malavalli, Shrirangapattana, Pandavapura, K R Pete, Nagamangala \\
(Southern & Mysore & Mysore, K R Nagar, T Narasipura, Nanjanagudu \\
DryZone) & Chamrajnagar & Chamrajnagar, Yalanduru, Gundlupet, Kollegala \\
& Tumakuru & Tumakuru, Kunigal, Tipaturu \\
& Hassan & Channarayapattana, Arasikere \\
\hline
\end{tabular}

periods in the data matrix window in the top right and onset date indicator at the bottom (both date and days after start of simulation).

\section{GIS mapping}

ArcGIS, widely used GIS software in research and development purposes, was employed in this study. Georeferencing of administrative map of DryZones of Southern Karnataka and digitization of district boundaries were carried out. Then output data pertaining to agro-climatic onset dates were linked to the polygon map of the study area. Thematic maps pertaining to these parameters were generated using ArcGIS 10.2.2 software.

\section{RESULTS AND DISCUSSION}

\section{Rainfall variability in the study area}

Monthly average rainfall of 50 and 30 years over the three dry zones $(4,5$ and 6$)$ of southern Karnataka is depicted in Fig.1. Rainfall in all the zones is distributed in bimodal pattern attaining a peak at May and September (Venkatesh et. al. 2016). In zone 4, 20.1 per cent (123 mm) of total rainfall is received during Jan to May months, 49.6 per cent $(303 \mathrm{~mm}$ ) during June to September period and remaining 30.3 per cent during October to December (185 $\mathrm{mm})$. In Zone 5, 19.2 per cent (149 $\mathrm{mm}$ ) of total rainfall is received during January to May months, 52.1 per cent (404 $\mathrm{mm}$ ) during June to September period and remaining 28.7 per cent during October to December $(223 \mathrm{~mm})$ and in Zone
$6,27.4$ per cent $(201 \mathrm{~mm})$ of total rainfall is received during Jan to May months, 41 per cent ( $301 \mathrm{~mm}$ ) during June to September period and remaining 31.6 per cent $(232 \mathrm{~mm})$ during October to December.

\section{Sowing and rainfall}

In Southern Karnataka, two different sowing strategies are used: 'dry seeding' and 'wet seeding'. The former strategy consists of sowing before the rains, i.e. when the soil is still dry. This practice tends to ease the germination, reduces the time needed to prepare farmable land before the first rains. However, this strategy is risky since high soil temperatures associated with dry weather as well as scarce and erratic rainfall before the full installation of the monsoon, which are insufficient for a full germination of the plant, may spoil the seeds (Graef and Haigis, 2001). As the temporal rainfall variability increased, this strategy is less used (McCorkle, 1994). Most farmers await a significant rainy event and sow the crops on the same day or the day after. Majority of the area is sown in 5 consecutive days after rainfall. However, this practice does not eliminate the risk of sowing failure in case of a dry spell just after the sowing.

\section{Sowing date based on agro-climatic onset}

Zone 4: Being a dry zone, receives an average rainfall of $608.8 \mathrm{~mm}$, most of it is received during the month of April and May as a pre monsoon showers (Venkatesh et. al. 2016). Simulation was carried out for all the stations coming under each taluk of four districts of the zone. The result showed 
Table 2: Meteorological stations in Karnataka used in the study along with their location and the average annual rainfall amount

\begin{tabular}{|c|c|c|c|c|c|c|c|c|c|}
\hline $\begin{array}{l}\text { Sl. } \\
\text { No. }\end{array}$ & Station & $\begin{array}{l}\text { Latitude } \\
\left({ }^{\circ} \mathrm{N}\right)\end{array}$ & $\begin{array}{l}\text { Longitude } \\
\left({ }^{\circ} \mathrm{E}\right)\end{array}$ & $\begin{array}{l}\text { Annual } \\
\text { Rainfall } \\
(\mathrm{mm})\end{array}$ & $\begin{array}{l}\text { Sl. } \\
\text { No. }\end{array}$ & Station & $\begin{array}{l}\text { Latitude } \\
\left({ }^{\circ} \mathrm{N}\right)\end{array}$ & $\begin{array}{l}\text { Longitude } \\
\left({ }^{\circ} \mathrm{E}\right)\end{array}$ & $\begin{array}{l}\text { Annual } \\
\text { Rainfall } \\
(\mathrm{mm}) \\
\end{array}$ \\
\hline 1 & Chitradurga & 14.23 & 76.29 & 641.69 & 27 & Malur & 13 & 77.94 & 745.46 \\
\hline 2 & Hosadurga & 13.79 & 76.28 & 687.65 & 28 & Mulabagilu & 13.16 & 78.39 & 804.32 \\
\hline 3 & Challakere & 14.31 & 76.65 & 620.86 & 29 & Chikkaballapur & 13.43 & 77.72 & 752.91 \\
\hline 4 & Molakalmuru & 14.71 & 76.74 & 552.91 & 30 & Chintamani & 13.4 & 78.05 & 781.06 \\
\hline 5 & Holalkere & 14.05 & 76.18 & 750.51 & 31 & Siddalaghatta & 13.39 & 77.86 & 682.88 \\
\hline 6 & Hiriyur & 13.94 & 76.61 & 589.99 & 32 & Gouribidanur & 13.61 & 77.51 & 717.26 \\
\hline 7 & Davanagere & 14.46 & 75.92 & 626.33 & 33 & Gudibande & 13.61 & 77.7 & 671.16 \\
\hline 8 & Harihara & 14.53 & 75.8 & 640.4 & 34 & Bagepalli & 13.78 & 77.79 & 648.47 \\
\hline 9 & Jagaluru & 14.52 & 76.33 & 555.78 & 35 & Maddur & 12.58 & 77.05 & 770.45 \\
\hline 10 & Madhugiri & 13.66 & 77.2 & 693.29 & 36 & Malavally & 12.38 & 77.05 & 687.7 \\
\hline 11 & Pavagadha & 14.1 & 77.28 & 596.17 & 37 & Mandya & 12.56 & 76.73 & 682.97 \\
\hline 12 & Sira & 13.74 & 76.89 & 666 & 38 & Pandavapura & 12.49 & 76.66 & 708.11 \\
\hline 13 & Chikkanayakanahalli & 13.42 & 76.6 & 715.43 & 39 & Shrirangapattana & 12.42 & 76.69 & 683.29 \\
\hline 14 & Tumkur & 13.33 & 77.11 & 864.59 & 40 & Krishnarajpete & 12.65 & 76.48 & 768.23 \\
\hline 15 & Gubbi & 13.31 & 76.91 & 792.83 & 41 & Nagamangala & 12.81 & 76.76 & 785.31 \\
\hline 16 & Devanahalli & 13.24 & 77.71 & 815.54 & 42 & K R Nagar & 12.43 & 76.38 & 675.87 \\
\hline 17 & Doddaballapur & 13.29 & 77.53 & 819.15 & 43 & Mysore & 12.29 & 76.64 & 776.2 \\
\hline 18 & Hoskote & 13.06 & 77.79 & 820.14 & 44 & Nanjanagud & 12.11 & 76.67 & 776.37 \\
\hline 19 & Ramanagara & 12.72 & 77.28 & 874 & 45 & T Narasipura & 12.42 & 76.71 & 762.95 \\
\hline 20 & Chanapattana & 12.65 & 77.2 & 823.94 & 46 & Gundlupet & 11.8 & 76.69 & 758.05 \\
\hline 21 & Kanakapura & 12.54 & 77.41 & 813.88 & 47 & Yelandur & 12.04 & 77.03 & 817.93 \\
\hline 22 & Magadi & 12.95 & 77.22 & 925.17 & 48 & Kunigal & 13.02 & 77.04 & 816.41 \\
\hline 23 & Banalore north & 12.97 & 77.59 & 962.58 & 49 & Tiptur & 13.26 & 77.46 & 711.21 \\
\hline 24 & Anekal & 12.7 & 77.69 & 860.11 & 50 & Channarayapattana & 12.9 & 76.38 & 687.47 \\
\hline 25 & Kolar & 13.13 & 78.12 & 774.9 & 51 & Arasikere & 13.31 & 76.25 & 731.86 \\
\hline 26 & Bangarpet & 12.99 & 78.17 & 695.43 & & & & & \\
\hline
\end{tabular}

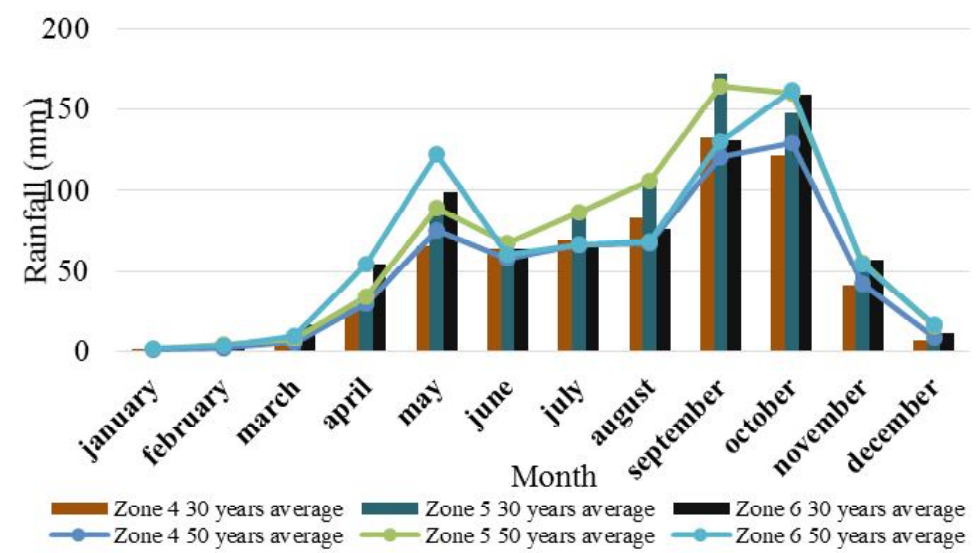

Fig. 1: Monthly average rainfall of 50 and 30 years over the three dry zones $(4,5$ and 6$)$ of southern Karnataka 


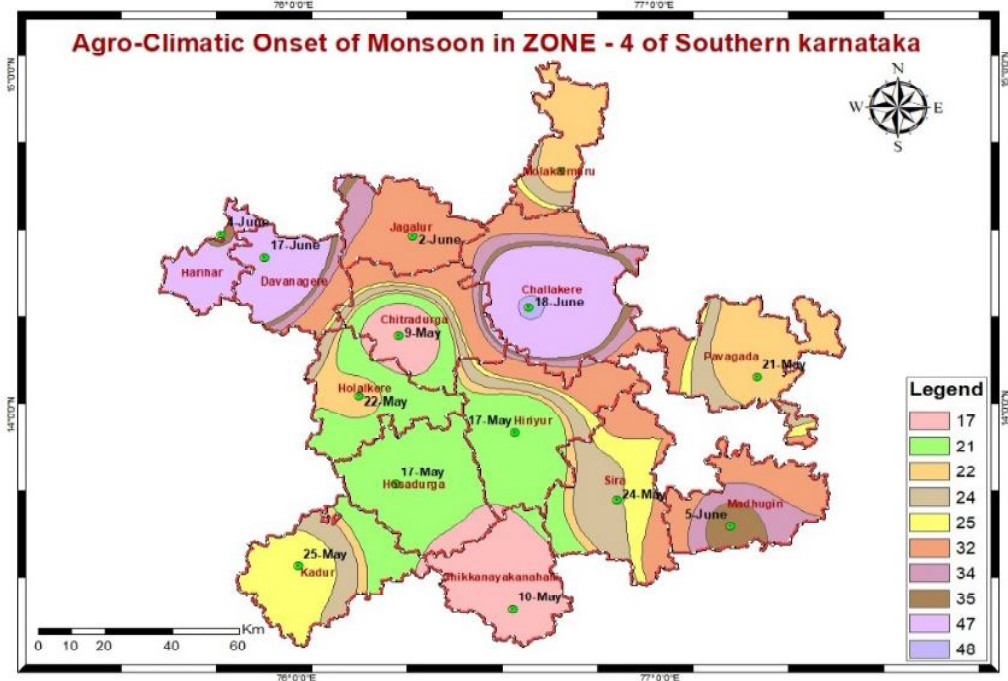

Fig. 2: ArcGIS maps indicating the Agro-climatic onset of monsoon in Zone-4 of Southern Karnataka

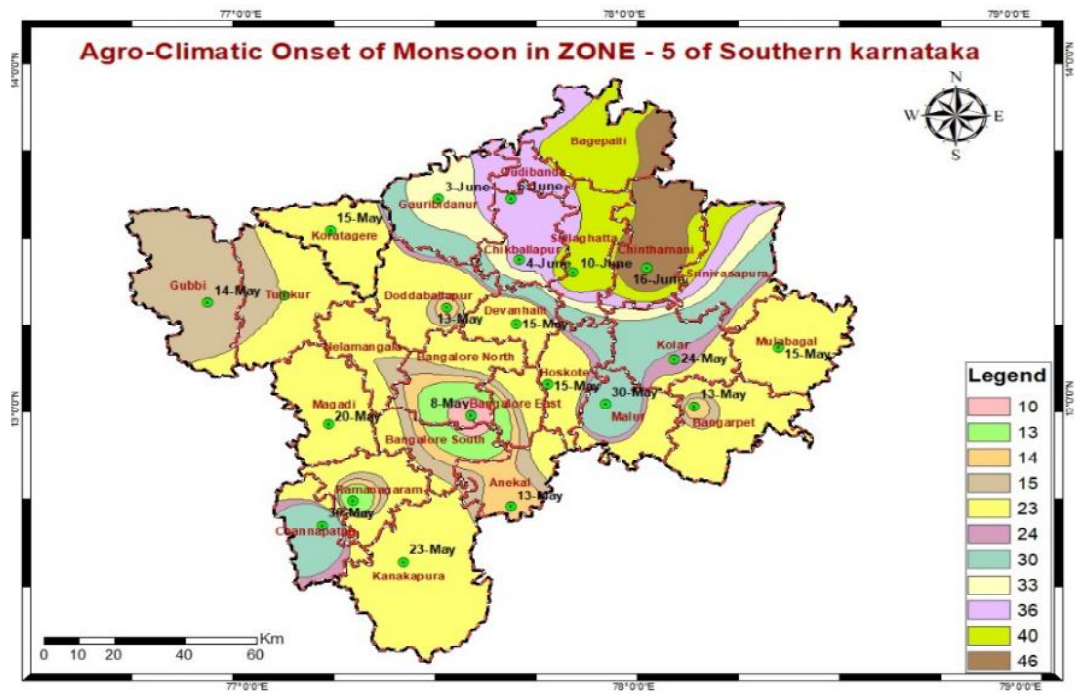

Fig. 3: ArcGIS maps indicating the Agro-climatic onset of monsoon in Zone-5 of Southern Karnataka

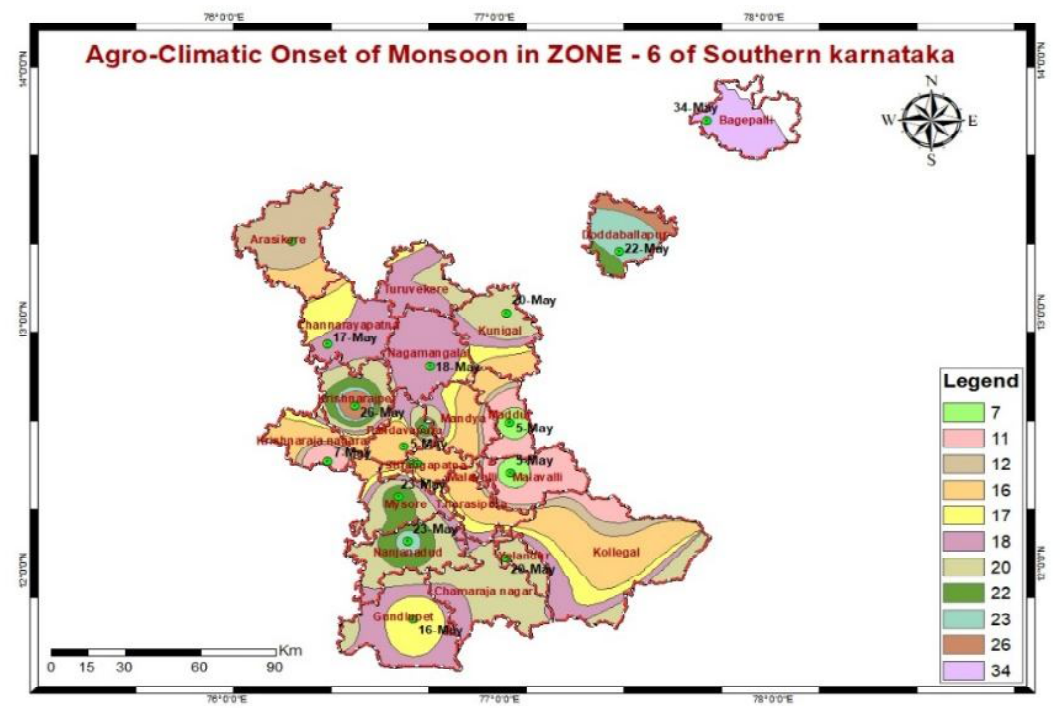

Fig. 4: ArcGIS maps indicating the Agro-climatic onset of monsoon in Zone-6 of Southern Karnataka 

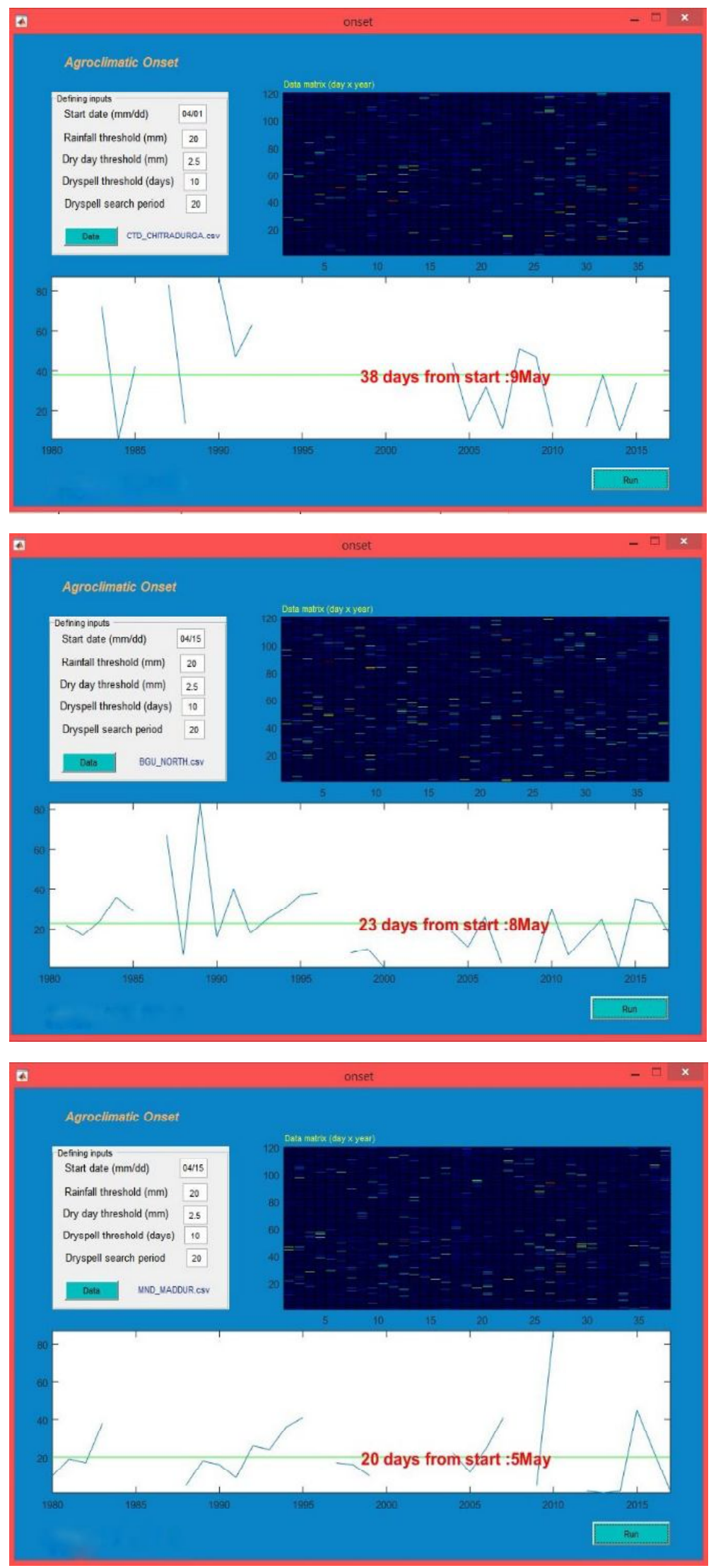

Fig. 5: MATLAB GUI showing earliest Agro-climatic onset dates (representative locations) of 3 Zones (top to bottom) of Southern Karnataka 
Table 3: Simulation results of running MatLab expressed in terms of days after start date and agro-climatic onset dates of Zone-

\begin{tabular}{llll}
\multicolumn{2}{c}{ 4 of Karnataka } & Days after start date & Agro-climatic onset date \\
\hline District & Taluk & 38 & 09 -May \\
\hline Chitradurga & Chitradurga & 32 & 17 -May \\
& Hosadurga & 34 & 18 -Jun \\
& Challakere & 30 & 21 -May \\
& Molakalmuru & 37 & 22 -May \\
& Holalkere & 32 & 17 -May \\
Davanagere & Diriyur & 33 & $17-$ June \\
& Davanagere & 34 & $04-$ June \\
& Harihara & 32 & $02-$ June \\
& Jagaluru & 35 & 05 - June \\
& Madhugiri & 36 & 21 -May \\
& Pavagadha & 39 & $24-$ May \\
& Sira & 25 & 10 -May \\
\hline
\end{tabular}

different onset dates for each taluk since the variability of rainfall amongst them (Table 3 and Fig. 2). Among all the taluks, an earlier date of $9^{\text {th }}$ May was predicted by the model (38 days after start of simulation. That is, April-15). Average of all the dates simulated for each station indicated that, fourteenth June will be the agro-climatic on set date (30 days after start of simulation. May-15).

Zone 5: This zone receives an average annual rainfall of $776.7 \mathrm{~mm}, 19.2$ percent $(149 \mathrm{~mm})$ of total rainfall is received during January to May months, 52.1 per cent (404 mm) during June to September period and remaining 28.7 per cent during October to December (223 mm) month (Venkatesh et. al. 2016). Due to this temporal and spatial variability of rainfall, different onset dates were simulated by the model for different taluks coming under each district of the zone (Table 4 and Fig. 3). Among all the taluks, an earlier date of $8^{\text {th }}$ May (23 days after start of the simulation. April 15 (as a start date) was predicted by the model for Bangalore north taluk. In this zone, $13^{\text {th }}$ June (28 days after start of simulation, May 15 as a start date) is said to be agro-climatic monsoon onset date after taking average of all the dates simulated for each station.

Zone 6: An average annual rainfall of $753.4 \mathrm{~mm}$ is received by this zone. Amongst $734 \mathrm{~mm}, 27.4$ per cent $(201 \mathrm{~mm})$ of total rainfall is received during Jan to May months, 41 per cent $(301 \mathrm{~mm})$ during June to September period and remaining 31.6 per cent $(232 \mathrm{~mm})$ during October to December(Venkatesh et al., 2016). Variability of simulated agro-climatic onset dates was expected due to the spatiotemporal variability of rainfall across each station of the zone (Vinaykumar et al., 2017). An earliest onset date $5^{\text {th }}$ May (20 days after start of simulation, April 15 as a start date) was simulated at Maddur, Malavally and Pandavapura taluks of Mandya (Table 5 and Fig. 4). Zonal average of $23^{\text {rd }}$ May (22 days after start of simulation, May $1^{\text {st }}$ as a start date).

The normal decision making rule to sow the crops in dry regions of southern Karnataka is, waiting for the first rainy event receiving at least $20 \mathrm{~mm}$ and sowing immediately (but, sometime even if the rainfall is not necessarily more than $20 \mathrm{~mm}$ ), even though, dry-seeding is practiced under anticipated rainfall, may end up with the losses right after sowing since the first wet event is not always followed by the full installation of the monsoon which usually occurs later than the first wet spell (Sultan et al., 2003), dry spells could occur afterwards, i.e. during the early stages of the crop growth. If a dry spell lasting more than 7 days is often associated with failure of the crop and re-sowing is necessary. So it is better to take into account of rainfall threshold, dry day threshold, and dry spell threshold etc. rainfall variables in order to arrive at a perfect date of onset suitable for the sowing without initial losses to the farmer. As we analysed the rainfall data from 1980 to 2018 , we observed that there was a shift in rainfall pattern in southern Karnataka (Fig. 1) causing early onset and cessation of monsoon. Under such conditions, by considering defining inputs like rainfall threshold, dry day threshold, dry spell threshold etc., we estimated date of onset was $15^{\text {th }}$ of May month in most parts 
Table 4: Simulation results of running MatLab expressed in terms of days after start date and agro-climatic onset dates of Zone5 of Karnataka

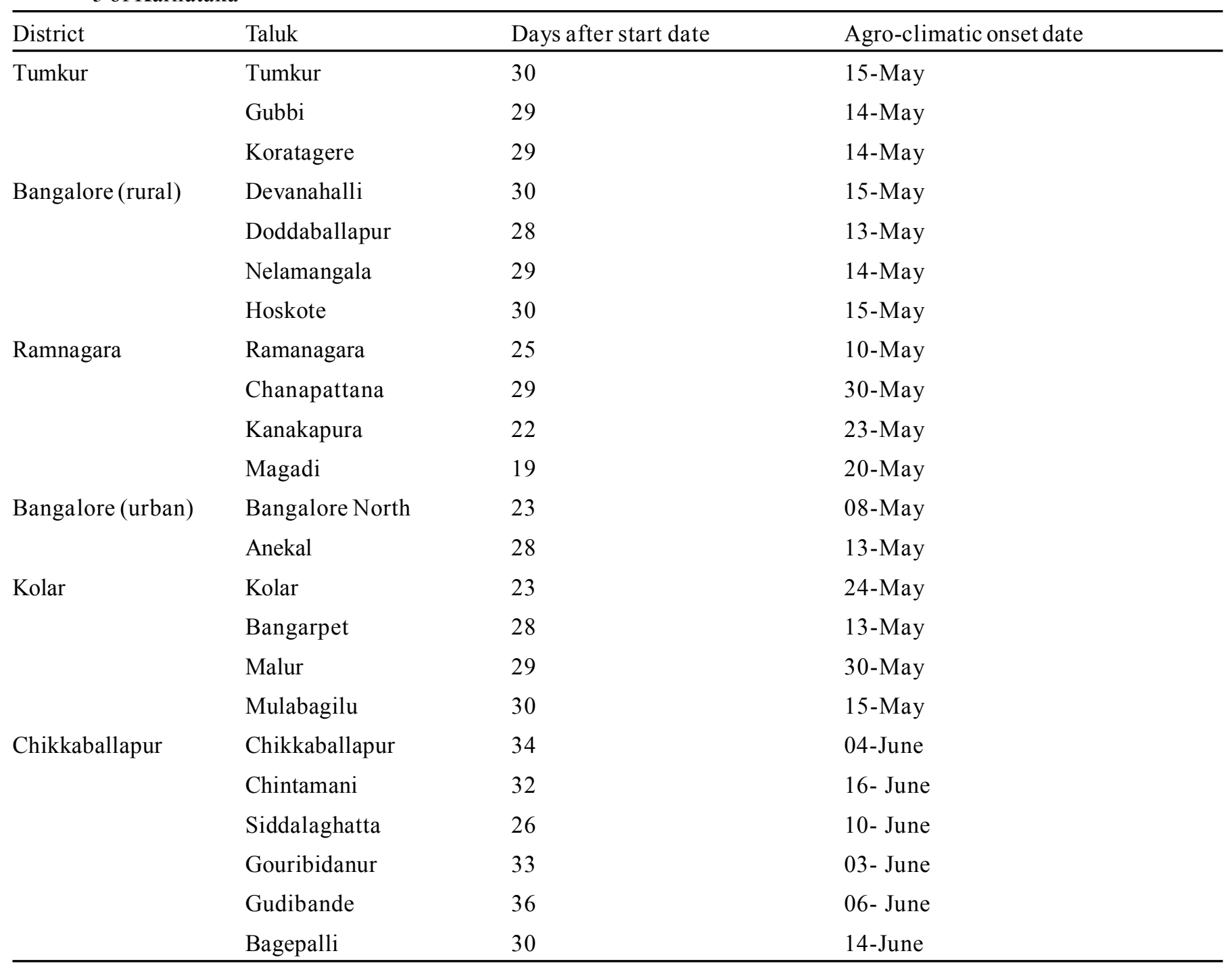

of the southern Karnataka. Further, there is a need to subjective tuning (namely amount of rainfall and length of the initial wet spell, length and intensity of post-onset dry spell, etc.) since the onset date is equivocal (Marteau et al., 2009; Marteau, 2010). In the future, efforts should be made to balance the effect of onset date with other intra-seasonal characteristics of the rainy season, notably the wet/dry spells distribution, especially close to the end of the rainy season. Any medium-term or seasonal prediction of the timing/ intensity of the monsoon's withdrawal would thus have a critical impact.

\section{CONCLUSION}

In crop production, the non-monetary inputs like date of sowing, spacing, etc., play a vital role. In dry zones of southern Karnataka, the traditional method followed by the farmers for sowing of the crops (soon after receiving of first rainfall) affect crop germination and initial growth due to moisture availability constraints right after sowing. As the results showed that trends in rainfall are shifting towards April-May, there was a need to search for an alternative for reducing crop losses. Agro-climatic onset of cropping season acts as an alternative for making decisions on selecting proper sowing date since the methodology considers many parameters like rainfall threshold, dry day threshold, dry spell threshold and dry spell search period along with the post-rainfall events. In all the three dry farming ones of southern Karnataka, the agro-climatic onset of cropping season is earlier as compared to the traditional sowing dates. Thus, advancements in sowing of crops based on the agroclimatic onset should be taken into account along with all other possible interventions for betterment of crop production. 
Table 5: Simulation results of running MatLab expressed in terms of days after start date and agro-climatic onset dates of Zone6 of Karnataka

\begin{tabular}{|c|c|c|c|}
\hline District & Taluk & Days after start date & Agro-climatic onset date \\
\hline \multirow[t]{7}{*}{ Mandya } & Maddur & 20 & 05-May \\
\hline & Malavally & 20 & 05-May \\
\hline & Mandya & 22 & 23-May \\
\hline & Pandavapura & 20 & 05-May \\
\hline & Shrirangapattana & 19 & 20-May \\
\hline & Krishnarajpete & 25 & 26-May \\
\hline & Nagamangala & 17 & 18-May \\
\hline \multirow[t]{4}{*}{ Mysore } & KR Nagar & 22 & 07-May \\
\hline & Mysore & 22 & 23-May \\
\hline & Nanjanagud & 22 & 23-May \\
\hline & T Narasipura & 27 & 12-May \\
\hline \multirow[t]{3}{*}{ Chamrajnagar } & Chamrajnagar & 16 & 17-May \\
\hline & Gundlupet & 15 & 16-May \\
\hline & Yelandur & 19 & 20-May \\
\hline \multirow[t]{3}{*}{ Tumkur } & Turuvekere & 19 & 20-May \\
\hline & Kunigal & 19 & 20-May \\
\hline & Tiptur & 21 & 22-May \\
\hline \multirow[t]{2}{*}{ Hassan } & Channarayapattana & 32 & 17-May \\
\hline & Arasikere & 26 & 11-May \\
\hline
\end{tabular}

\section{AKNOWLEDGEMENTS}

This study was carried out through All India Coordinated Research Project on Agrometeorology, UAS, GKVK, Bangalore with the support of the Central Research Institute for Dryland Agriculture (CRIDA).

\section{REFERENCES}

Andrews, D.J.(1973). Effects of date of sowing on photosensitive Nigerian sorghums. Exp. Agric., 9: 337-346.

Bacci, L., Cantini, C., Pierini, F., Marachi, G. and Reyniers, F.N. (1999). Effects of sowing date and nitrogen fertilization on growth, development and yield of a short day cultivar of millet (Pennisetum glaucum L.). Eur. J. Agron., 10:921.

Balme, M., Galle, S. and Lebel, T. (2005). Start of the rainy season in the Sahel: variability on hydrological and agronomic scales, analyzed from EPSAT-Niger data. Secheresse, 16: 15-22.

Barbier, B., Yacouba, H., Karambiri, H., Zorome, M. and Some,
B. (2009). Human vulnerability to climate variability in the Sahel: Farmer's adaptation strategies in Northern Burkina Faso. J. Environ. Manage., 43: 790-803.

Graef, F. and Haigis, J. (2001). Spatial and temporal rainfall variability in the Sahel and its effects on farmers' management strategies. J. Arid. Environ., 48: 221-231.

Harish, P.S., Kapil, D.S., Gangireddy, S.R., and Kishori, L.S. (2004). Challenges and Strategies of Dryland Agriculture, Crop Science Society of America and American Society of Agronomy, Special Publication, 32: 67-92.

Houze, R.A. and Cheng, C.P. (1977). Radar characteristics of tropical convection observed during GATE: Mean properties and trends over the summer season. Mon. Weather Rev., 105: 964-980.

Ingram, K.T., Roncoli, M.C. and Kirshen, P.H. (2002). Opportunities and constraints for farmers of West Africa to use seasonal precipitation forecasts with BurkinaFaso as a case study. Agric. Syst., 74: 331-349. 
Kesava Rao,A.V.R., Suhas, P.W., Singh, K.K., IrshadAhmed, M., Srinivas, K., Snehal, D. B. and Ramadevi, O. (2013). Increased arid and semi-arid areas in India with associated shifts during 1971-2004. J. Agrometeorol., 15(1): 1118 .

Marteaua, R., Benjamin, S. Vincent. M., Agali. A., Christian, B. and Traore, S.B. (2011). The onset of the rainy season and farmers' sowing strategy for pearl millet cultivation in Southwest Niger. Agric. Forest Meteorol., 151: 13561369.

Mccorkle, C.M. (1994). Farmer Innovation in Niger. Studies in Technology and Social Change, Technology and Social Change Program. Iowa State University, Ames, Iowa, 48 pp.

Morris, R.A. and Zandstra, H.G. (1979). Land and climate in relation to cropping patterns in Rainfed lowland rice, Intl. Rice Res. Conference, IRRI, Philippines.

Omotosho, J.B. (1990). Onset of thunderstorms and precipitation overnorthern Nigeria. Int. J. Climatol., 10: 849-860.

Omotosho, J.B. (1992). Long-range prediction of the onset and end of the rainy season in the West African Sahel. Int. J. Climatol., 12: 369-382.

Omotosho, J.B., Balogun, A.A. and Ogunjobi, K. (2000). Predicting monthly and seasonal rainfall, onset and cessation of the rainy season in West Africa using only surface data. Int. J. Climatol., 20: 865-880.

Payne, W.A., Lascano, R.J., Hossner, L.R., Wendt, C.W. and Onken, A.B. (1991). Pearl Millet growth as affected by phosphorus and water. Agron. J., 83:942-948.

Ravindrababu, B.T., Rajegowda, M.B., Janardhanagowda, N.A. and Girish, J. (2010). Weekly, monthly and seasonal rainfall atBengaluru in Karnataka.J. Agrometeorol., 12 (2): 263-265.

Rockstrom, J. and De Rouw, A. (1997). Water, nutrients and slope position in on-farm millet cultivation in the Sahel. Plant Soil, 195: 311-327.

Sivakumar, M.V. (1988). Predicting rainy season potential from the onset of rains in southern sahelian and sudanian climatic zones of West Africa. Agric. Forest Meteorol., 42: 295-305.
Sivakumar, M.V. (1992). Empirical analysis of dry spells for agricultural applications in West Africa. J. Climate, 5: 532-539.

Soler, C.M.T., Maman, N., Zhang, X., Mason, S.C. and Hoogenboom, G. (2008). Determining optimum planting dates for pearl millet for two contrasting environments using a modelling approach. J. Agric. Sci., 146: 445459.

Sparling, G.P., and Ross, D.J. (1988). Microbial contribution to the increased nitrogen mineralization after air-drying of soils. Plant Soil, 105: 163-167.

Stoop, W.A., Pattanayak, C.M., Matlon, P.J. and Root, W.R. (1981).A strategy to raise the productivityof subsistence farming systems in the WestAfrican semi-arid tropics. In: Proceedings Sorghum in the Eighties, ICRISAT, Patancheru, India, pp. 519-526.

Sultan, B. and Janicot, S. (2003). The West African Monsoon Dynamics - The "Pre-onset" and "Onset" of the Summer Monsoon. J. Climate, 16: 3407-3427.

Tiwari, A.K., Sharma, A.K. and Srivastava, M.M. (1992). Probability analysis of rainfall data of Datia district, Bundelkhand for crop planning, Indian J. Soil Cons., 20(3): 82-88.

Venkatesh, H., Shivaramu, H.S., Rajegowda, M.B. and Rao, V.U.M. (2016). Agroclimatic atlas of Karnataka, pp 211.

Vinaya Kumar, H.M., Shivamurthy, M. and Lunagaria, M.M. (2017). Impact of rainfall variability and trend on rice yield in coastal Karnataka. J. Agrometeorol., 19 (3): 286-287.

Wani, S.P., Sahrawat, K.L., Sarvesh, K.V., Baburao, M. and Krishnappa, K. (2011). Soil Fertility Atlas for Karnataka, India. International Crops Research Institute for the Semi-Arid Tropics, Andhra Pradesh, India: 312 pp. 